\title{
The study of surface oxidation of tin(II) fluoride and chloride fluoride materials by Mössbauer spectroscopy: to oxidize or not to oxidize, that is the question
}

\author{
G. Dénès, E. Laou, M. C. Madamba \& A. Muntasar \\ Laboratory of Solid State Chemistry and Mössbauer Spectroscopy, \\ Department of Chemistry and Biochemistry, Concordia University, \\ Montréal, Canada
}

\begin{abstract}
Experimental methods designed to study the bulk of materials do not necessarily detect the changes taking place at the surface of the crystallites. For example, divalent tin-containing materials appear to be stable at ambient conditions in air, provided they are not hygroscopic, X-ray powder diffraction shows only the peaks of the expected tin(II) phase. However, we have observed that the Mössbauer spectrum of polycrystalline samples contain, in addition to the expected tin(II) peak(s), a small peak at $0 \mathrm{~mm}$ s relative to $\mathrm{CaSnO}_{3}$ at ambient conditions, that can be attributed only to tin(IV) coordinated by oxygen. A detailed study of this phenomenon has shown that Mössbauer spectroscopy is quite sensitive for detecting thin layers of oxide at the surface of crystallites of tin(II). This phenomenon has been exploited for the study of spontaneous oxidation of various tin(II) fluoride and chloride-containing materials, some of these fluorides being the highest performance fluoride-ion conductors known to date. It was observed that passivation is quite efficient in the fluorides, and in the chloride fluorides that have all their tin(II) covalently bonded. On the other hand, the materials containing a mixture of covalently bonded tin(II) and the $\mathrm{Sn}^{2+}$ stannous ion namely, the $\mathrm{Ba}_{1-\mathrm{x}} \mathrm{Sn}_{\mathrm{x}} \mathrm{Cl}_{1+\mathrm{y}} \mathrm{F}_{1-\mathrm{y}}$ solid solution, show a higher rate of oxidation, which is highly dependent on the method of preparation and the composition parameters, $x$ and $y$.

Keywords: passivation, oxidation, disordered phases, fluorite-type structure, Mössbauer spectroscopy, X-ray diffraction, ionic conductivity, BaClF.
\end{abstract}




\section{Introduction}

The $\mathrm{MF}_{2}$ fluorides of large divalent metals $(\mathrm{M}=\mathrm{Ca}, \mathrm{Sr}, \mathrm{Ba} \& \mathrm{~Pb})$ have the well known fluorite type structure, with a cubic unit-cell, space group Fm3m, and a cubic coordination of the metal ion (fig. 1) [1]. This contrasts with $\mathrm{SnF}_{2} \operatorname{tin}(\mathrm{II})$ fluoride (stannous fluoride) that has a molecular structure; it is made of $\mathrm{Sn}_{4} \mathrm{~F}_{8}$ tetramers and the $\mathrm{Sn}-\mathrm{F}$ bonds are strongly covalent [2]. When $\mathrm{SnF}_{2}$ and $\mathrm{MF}_{2}$ are combined together, some new materials are produced, some of which are ordered, others disordered. The $\mathrm{MSnF}_{4}$ compounds have a ...M M Sn Sn... order parallel to the $c$ axis of the unit-cell (fig. 1) [3]. Tin and lead belong to group 14, and therefore they have four valence electrons, and in the +2 suboxidation state, the $5 s^{2}(\mathrm{Sn})$ or $6 s^{2}(\mathrm{~Pb})$ electrons are unused and form a nonbonding electron pair, also called a lone pair. When bonding is ionic, the orbitals are not hybridized and the lone pair is located on the $n s$ native orbital that has spherical symmetry, unless it is distorted by polarization, and a quite regular coordination is observed, and the lone pair is said to be non-stereoactive since it does not modify the coordination. In fluorite-type $\beta-\mathrm{PbF}_{2}$, lead has a cubic coordination, therefore its lone pair is located on the native $6 s$ orbital and bonding is ionic, like in $\mathrm{BaF}_{2}$ (fig. 1). In tetragonal $\mathrm{MSnF}_{4}$, the coordination of $\mathrm{M}$ is a distortion of the $\mathrm{MF}_{8}$ cube of the fluorite structure, with in addition, four longer interactions, to form an overall $\mathrm{MF}_{4} \mathrm{~F}{ }_{4} \mathrm{~F}{ }_{4}$ where the bond length increases as follows: M-F (from M-F-M bridges) $<\mathrm{M}-\mathrm{F}^{\prime}$ (from $\mathrm{M}-\mathrm{F}_{\mathrm{eq}}-\mathrm{Sn}$ bridges) $<\mathrm{M}-\mathrm{F}$ " (from M-F $\mathrm{Fx}_{\mathrm{ax}}-\mathrm{Sn}$ bridges), where $\mathrm{F}_{\mathrm{eq}}$ and $\mathrm{F}_{\mathrm{ax}}$ form equatorial (4) and axial (1) bonds with tin, respectively (fig. 1). For the sake of clarity, the BaF" bonds are not shown on figure 1 . The lead coordination in $\beta-\mathrm{PbF}_{2}$, is still ionic since $\mathrm{Sr}^{2+}$ and $\mathrm{Ba}^{2+}$ take the same coordination in $\mathrm{SrSnF}_{4}$ and in $\mathrm{BaSnF}_{4}$, respectively. In contrast, tin forms covalent bonding in $\mathrm{MSnF}_{4}$, with a very short axial Sn-F" bond, and the lone pair is located on a hybrid orbital, in transposition to F" (fig. 1). The tin lone pair is said to be stereoactive since it changes drastically the tin stereochemistry (lower coordination number, highly distorted coordination). A consequence of the $\mathrm{M} / \mathrm{Sn}$ order and of the stereoactivity of the tin lone pair is that the lone pairs cluster in sheets that are cleavage planes, which make the structure very highly two-dimensional. Examples of disordered structures are $\mathrm{PbSn}_{4} \mathrm{~F}_{10}$, the $\mathrm{M}_{1-\mathrm{x}} \mathrm{Sn}_{\mathrm{x}} \mathrm{F}_{2}$ solid solution $(\mathrm{M}=\mathrm{Ca}$ and $\mathrm{Pb})$, and $\mu \gamma$ $\mathrm{MSnF}_{4}(\mathrm{M}=\mathrm{Ba}$ and $\mathrm{Pb})$ obtained by ball-milling. The disordered phases have an Fm3m cubic unit-cell like the fluorite-type $\mathrm{MF}_{2}$, and their diffraction pattern shows no peak splitting or additional low angle peak that would indicate the presence of a lattice distortion or a superstructure. Therefore, Sn and the other metal $\mathrm{M}$ are fully disordered on the metal ion site of the $\mathrm{MF}_{2}$ structure (fig. 2). The $\mathrm{M}$ bonding is ionic and the coordination is cubic with some disordered local distortions in the neighborhood of tin, while tin bind to only one of the faces of the $F_{8}$ cubes, with its stereoactive lone pair pointing towards the center of the cube, and thus its bonding is covalent. $\mathrm{BaClF}$ crystallizes in the $\mathrm{PbClF}$ structure (space group $\mathrm{P} 4 / \mathrm{nmm}$ ). Its structure is also a tetragonal distortion of the fluoritetype $\mathrm{BaF}_{2}$, with layers of $\mathrm{F}$ and $\mathrm{Cl}$ ordered parallel to the $c$ axis of the unit-cell, making it a layered structure, in contrast with the three-dimensional cubic 
structure of $\mathrm{BaF}_{2}$ (fig. 1). We have recently found two methods for substituting substantial amounts of $\mathrm{Ba}$ by $\mathrm{Sn}$ in $\mathrm{BaClF}$, and also some $\mathrm{F}$ by $\mathrm{Cl}(\mathrm{y}>0)$, or some $\mathrm{Cl}$ by $\mathrm{F}(\mathrm{y}<0)$, making it a doubly disordered $\mathrm{Ba}_{1-\mathrm{x}} \mathrm{Sn}_{\mathrm{x}} \mathrm{Cl}_{1+\mathrm{y}} \mathrm{F}_{1-\mathrm{y}}$ solid solution. $\mathrm{X}$ ray diffraction shows that $\mathrm{Ba}$ and $\mathrm{Sn}$ are fully disordered on the $\mathrm{Ba}$ site of the $\mathrm{BaClF}$ structure. In addition, while the two anionic sites remain ordered, for $\mathrm{y}>0$ the $\mathrm{y} \mathrm{Cl}$ in excess are disordered with the remaining $(1-\mathrm{y}) \mathrm{F}$ on the $\mathrm{F}$ site, whereas for $\mathrm{y}<0$, the $(-\mathrm{y})$ excess $\mathrm{F}$ are disordered with the remaining $(1+\mathrm{y}) \mathrm{Cl}$ on the $\mathrm{Cl}$ site. However, the electronic situation at tin cannot be assessed by X-ray diffraction. All the tin(II)-containing fluorides studied here are high performance fluoride ion conductors (about three orders of magnitude higher than the conductivity of the corresponding $\mathrm{MF}_{2}$ ).
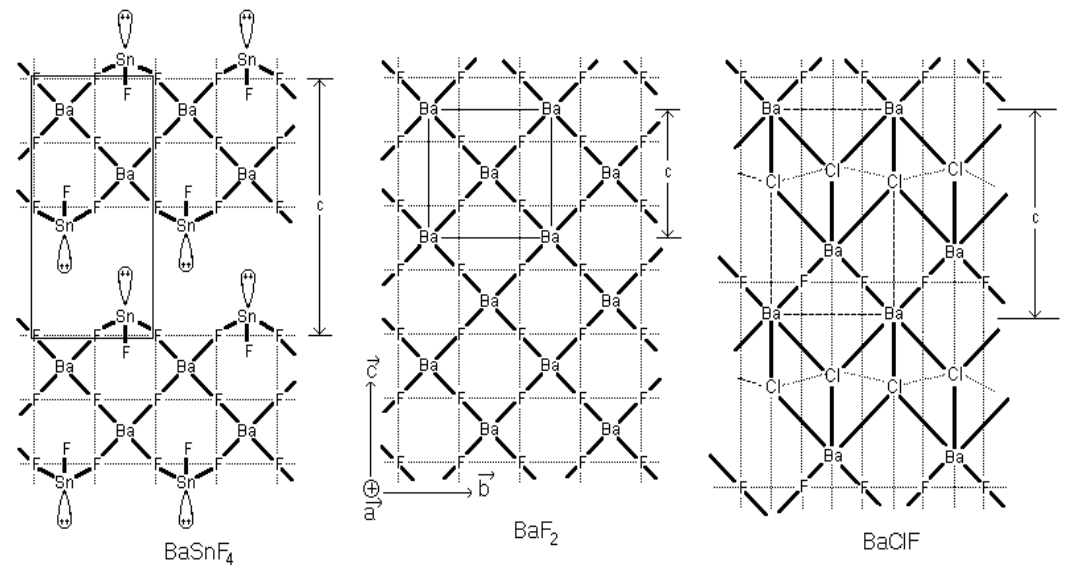

Figure 1: $\quad$ Projection of the crystal structure of $\mathrm{BaSnF}_{4}, \mathrm{BaF}_{2}$ and $\mathrm{BaClF}$.

All these materials appear stable in air at ambient conditions, and X-ray diffraction shows no sign of oxidation to tin(IV). The present study shows that tin-119 Mössbauer spectroscopy is an excellent method for detecting minute amounts of tin(IV) oxide in tin(II) compounds, and that all materials show at the minimum some surface oxidation, and some passivate very well while other do so less efficiently.

\section{Experimental}

Fluoride materials synthesis was carried out either in aqueous medium or at high temperature under dry conditions. Tetragonal $\alpha-\mathrm{PbSnF}_{4}$ was obtained by precipitation on addition of an aqueous solution of lead(II) nitrate to a solution of $\mathrm{SnF}_{2}$. $\mathrm{Ca}_{1-\mathrm{x}} \mathrm{Sn}_{\mathrm{x}} \mathrm{F}_{2}$ precipitated when a solution of calcium nitrate was added to a solution of $\mathrm{SnF}_{2}$ at high $\mathrm{Ca} / \mathrm{Sn}$ ratio, or by leaching, on stirring, $\mathrm{CaSn}_{2} \mathrm{~F}_{6}$ in a large amount of water. The synthesis of $\mathrm{Pb}_{1-\mathrm{x}} \mathrm{Sn}_{\mathrm{x}} \mathrm{F}_{2}$ and $\mathrm{BaSnF}_{4}$ was carried out under nitrogen in sealed copper tubes heated at $500{ }^{\circ} \mathrm{C}$ and quenched. Barium 
tin(II) chloride fluorides were prepared by reaction of barium nitrate and tin(II) fluoride in aqueous solutions versus the $\mathrm{X}=\mathrm{BaCl}_{2} /\left(\mathrm{SnF}_{2}+\mathrm{BaCl}_{2}\right)$ molar ratio. Three new materials were obtained: $\mathrm{BaSn}_{2} \mathrm{Cl}_{2} \mathrm{~F}_{4} \quad(0.25<\mathrm{X}<0.35)$, $\mathrm{BaSnClF}_{3} \cdot 0.8 \mathrm{H}_{2} \mathrm{O}(0.50<\mathrm{X}<0.80)$, and a material that has the diffraction pattern of $\mathrm{BaClF}(\mathrm{X}>0.87)$. Chemical analysis showed that it is a $\mathrm{Ba}_{1-\mathrm{x}} \mathrm{Sn}_{\mathrm{x}} \mathrm{Cl}_{1+\mathrm{y}} \mathrm{F}_{1-\mathrm{y}}$ solid solution $(\mathrm{x}=0.15, \mathrm{y}=0.11)$. A very similar "BaClF phase" was obtained by synthesis in dry conditions when mixtures calculated according to eqn (1) were heated three days under nitrogen in sealed copper tubes at temperatures varying from 350 to $800{ }^{\circ} \mathrm{C}$.

$$
\frac{1-2 x-y}{2} \mathrm{BaF}_{2}+x \mathrm{SnF}_{2}+\frac{1+y}{2} \mathrm{BaCl}_{2} \rightarrow B a_{1-x} S n_{x} C l_{1+y} F_{1-y}
$$

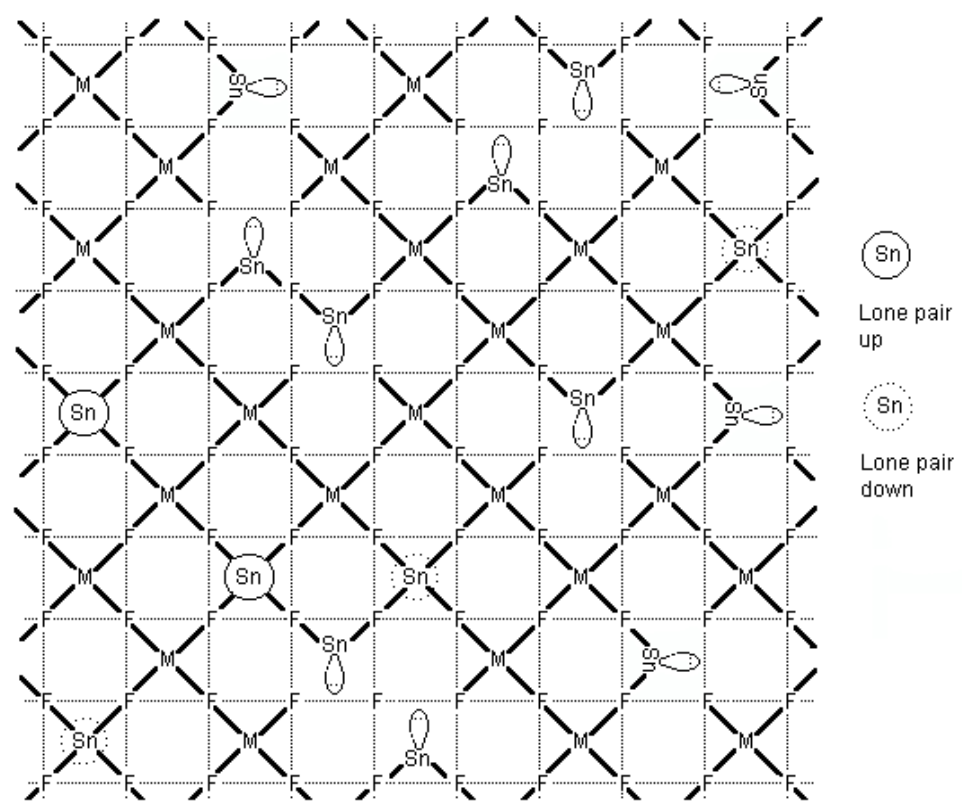

Figure 2: $\quad$ Model of a disordered fluorite type $\mathrm{M}_{1-\mathrm{x}} \mathrm{Sn}_{\mathrm{x}} \mathrm{F}_{2}$ structure.

X-ray powder diffraction was carried out on a PW-1050/25 Philips diffractometer automated with the SIE RAY $122^{\circledR}$ system from Diffraction Technology, using the $\mathrm{K}_{\alpha}$ radiation of copper $\left(\lambda_{\mathrm{K} \alpha 1}=1.54051 \AA\right)$ and a monochromator. Mössbauer spectra were recorded in a TN7200 ${ }^{\circledR}$ multichannel analyzer from Tracor Northern, using an Elscint driving system, a Harshaw (Tl) $\mathrm{NaI}$ detector and a $10 \mathrm{mCi} \mathrm{CaSnO}_{3} \gamma$-ray source. All chemical isomer shifts were referenced relative to a standard $\mathrm{CaSnO}_{3}$ absorber. All spectra were collected at ambient temperature and fitted using the GMFP software. Samples were studied when young (freshly prepared) and old (after several years storage in air at ambient temperature). 

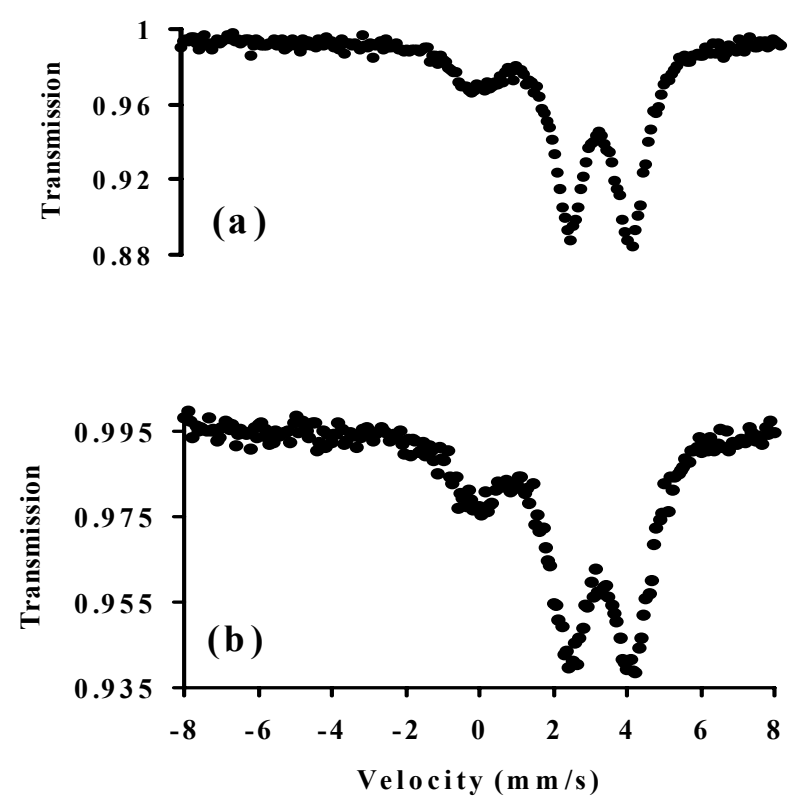

Figure 3: Ambient temperature ${ }^{119} \mathrm{Sn}$ Mössbauer of $\mathrm{BaSnF}_{4}$ prepared by the dry method at $500{ }^{\circ} \mathrm{C}$ for 2 hours: (a) young sample, (b) sample aged for 69 months at ambient conditions.

\section{Results and discussion}

\subsection{Oxidation of the fluorides}

Various ordered and disordered tin(II)-containing fluorides were checked for oxidation, using X-ray diffraction and Mössbauer spectroscopy. Figure 3 shows the spectrum of $\mathrm{BaSnF}_{4}$ when freshly prepared and after 69 months of age. Both spectra have a large quadrupole doublet in the $2-4 \mathrm{~mm} / \mathrm{s}$ velocity range, which is characteristic of the presence of a stereoactive lone pair on tin, and confirms that bonding is covalent (fig. 1). In addition, a weak peak is observed at ca. $0 \mathrm{~mm} / \mathrm{s}$. The peaks positions are given relative to a tin(IV) oxide standard, $\mathrm{CaSnO}_{3}$, and therefore, the peak at $0 \mathrm{~mm} / \mathrm{s}$ in $\mathrm{BaSnF}_{4}$ shows some tin(IV) oxide is contained in the ample, even when freshly prepared. This can be assigned to $\mathrm{Sn}$ (II) to $\mathrm{Sn}(\mathrm{IV})$ oxidation of the surface of the solid particles by atmospheric oxygen. After aging 69 months in air at ambient conditions, the tin(IV) signal at ca. 0 $\mathrm{mm} / \mathrm{s}$ has not increased significantly, therefore no much further oxidation occurred during the nearly 6 years of aging. It is therefore established that there is an initial very rapid surface oxidation of the particles that creates a passivating layer, which protects the bulk of the particles against further oxidation. X-ray diffraction does not show any peak foreign to $\mathrm{BaSnF}_{4}$, and more particularly no 
$\mathrm{SnO}_{2}$ peak. This suggests that either the amount of $\mathrm{SnO}_{2}$ is too small to be detected by diffraction, or the oxide is amorphous, or the particles are too small to diffract. This establishes the superiority of Mössbauer spectroscopy to detect small amounts of oxide in tin(II) halides. The relative intensity of Mössbauer peaks is a function of both the amount of each kind of tin and their recoil-free fraction $f_{a}$. The recoil-free fraction is the fraction of ${ }^{119} \mathrm{Sn}$ nuclei that absorb $\gamma$-rays without dissipating the recoil energy through phonons (lattice vibrations). The stronger the lattice, the higher the recoil-free fraction, and the stronger the Mössbauer peaks at equal amount of tin. Since $\operatorname{Sn}(\mathrm{IV})$ forms very strong bonds to oxygen in the highly tight rutile structure of $\mathrm{SnO}_{2}$, it has a high recoil-free fraction and gives a disproportionably high signal, in comparison with small recoil-free fraction tin(II) halides, that have much weaker bonds. It results that the fraction of $\mathrm{SnO}_{2}$ in a tin(II) halide is more than ten times smaller than its relative signal. Therefore, the amount of $\mathrm{SnO}_{2}$ in $\mathrm{BaSnF}_{4}$ is much smaller than the intensity of it signal suggests. Disordered systems, even very poor in tin, like the $\mathrm{M}_{1-\mathrm{x}} \mathrm{Sn}_{\mathrm{x}} \mathrm{F}_{2}$ at small tin content $(\mathrm{x}=0.27$ for $\mathrm{M}=\mathrm{Ca}, \mathrm{x}=0.10$ for $\mathrm{M}=\mathrm{Pb}$ ) also show no $\mathrm{SnO}_{2}$ diffraction peak (fig. 4Ab), and the tin(IV) Mössbauer peak is barely detectable (fig. $4 \mathrm{Cb}$ ), showing excellent passivation.

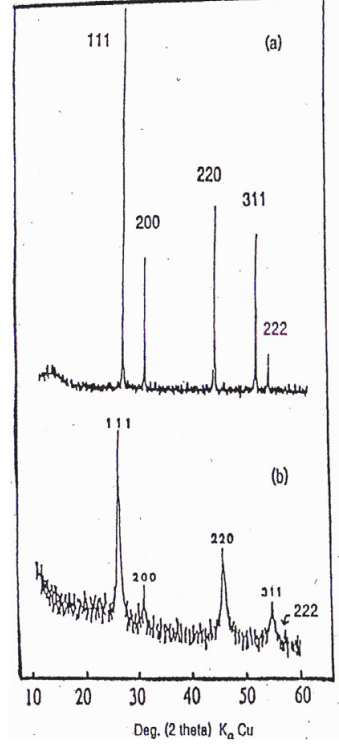

(A)

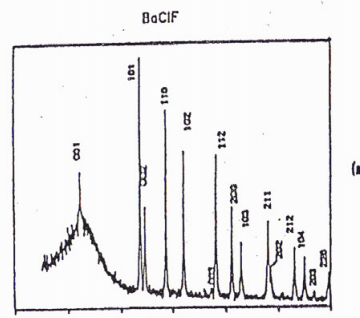

$B 0(5.66) \operatorname{SnCl}(7.30) F(6.04)$

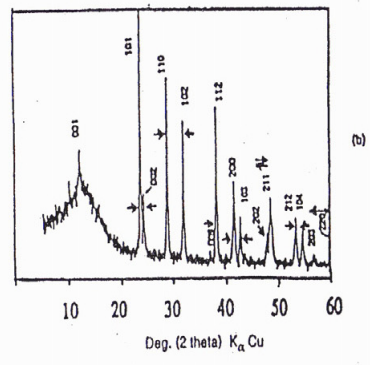

(B)

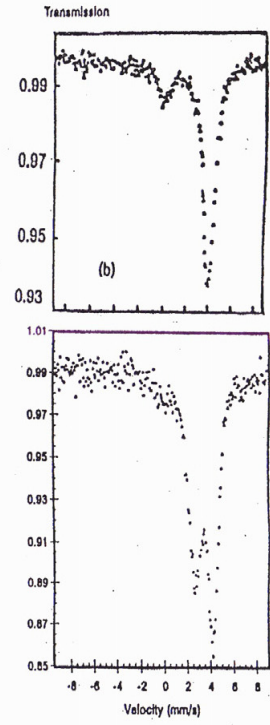

(C)

Figure 4: (A) X-ray powder diffraction pattern of $\mathrm{CaF}_{2}$ and $\mathrm{Ca}_{1-\mathrm{x}} \mathrm{Sn}_{\mathrm{x}} \mathrm{F}_{2}(\mathrm{x}=$ 0.27), (B) X-ray powder diffraction pattern of $\mathrm{BaClF}$ and $\mathrm{Ba}_{1-\mathrm{x}} \mathrm{Sn}_{\mathrm{x}} \mathrm{Cl}_{1+\mathrm{y}} \mathrm{F}_{1-\mathrm{y}}(\mathrm{x}=0.15, \mathrm{y}=0.094),(\mathrm{C}){ }^{119} \mathrm{Sn}$ ambient temperature Mössbauer spectrum of $\mathrm{Ba}_{1-\mathrm{x}} \mathrm{Sn}_{\mathrm{x}} \mathrm{Cl}_{1+\mathrm{y}} \mathrm{F}_{1-\mathrm{y}} \quad(\mathrm{x}=0.15, \mathrm{y}$ $=0.094)$ and $\mathrm{Ca}_{1-\mathrm{x}} \mathrm{Sn}_{\mathrm{x}} \mathrm{F}_{2}(\mathrm{x}=0.27)$. 


\subsection{Oxidation of the chloride fluorides}

The stoichiometric chloride fluorides, $\mathrm{BaSn}_{2} \mathrm{Cl}_{2} \mathrm{~F}_{4}$ and $\mathrm{BaSnClF}_{3} .0 .8 \mathrm{H}_{2} \mathrm{O}$ have a behavior similar to that of the fluorides. Freshly prepared samples have a tin(IV) oxide peak, and therefore there is a rapid initial surface oxidation (fig. 5), and it also does not show any significant increase after aging, therefore efficient passivation occurs. X-ray diffraction does not detect the oxide. The stronger tin(IV) Mössbauer signal of $\mathrm{BaSn}_{2} \mathrm{Cl}_{2} \mathrm{~F}_{4}$, in comparison to $\mathrm{BaSnClF}_{3} \cdot 0.8 \mathrm{H}_{2} \mathrm{O}$, does not mean that the former compound contains more $\mathrm{SnO}_{2}$. It could just mean that tin(II) in $\mathrm{BaSn}_{2} \mathrm{Cl}_{2} \mathrm{~F}_{4}$ has a lower recoil-free fraction than in $\mathrm{BaSnClF}_{3} \cdot 0.8 \mathrm{H}_{2} \mathrm{O}$. Very low temperature spectra would be required to determine the reason for their unequal tin(IV) peak intensity.
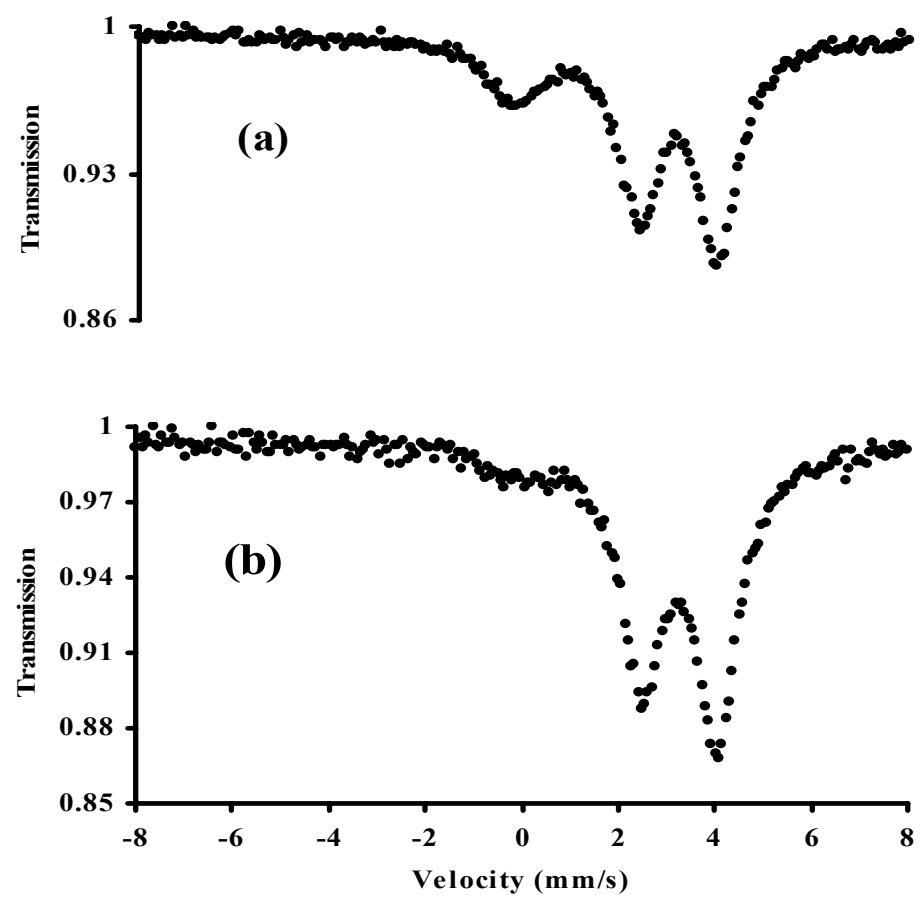

Figure 5: Ambient temperature ${ }^{119} \mathrm{Sn}$ Mössbauer spectrum of: (a) $\mathrm{BaSn}_{2} \mathrm{Cl}_{2} \mathrm{~F}_{4}$ and (b) $\mathrm{BaSnClF}_{3} \cdot 0.8 \mathrm{H}_{2} \mathrm{O}$.

The behavior of the non-stoichiometric $\mathrm{Ba}_{1-\mathrm{x}} \mathrm{Sn}_{\mathrm{x}} \mathrm{Cl}_{1+\mathrm{y}} \mathrm{F}_{1-\mathrm{y}}$ is much more complex. The Mössbauer spectrum of the precipitated solid solution is made of a single tin(II) line at ca. $4 \mathrm{~mm} / \mathrm{s}$, characteristic of ionic bonding, and of a tin(IV) oxide peak at ca. $0 \mathrm{~mm} / \mathrm{s}$ (figs. $4 \mathrm{Cb} \& 6$ ). Like in the materials above, no $\mathrm{SnO}_{2}$ could be detected by X-ray diffraction (fig. 4Bb). Contrary to the fluorides and the stoichiometric chloride fluorides, a significant increase of the intensity of the tin(IV) oxide Mössbauer peak takes place on aging for 4 years. Therefore, 
although the material is still quite well protected against oxidation, it is not fully passivated.
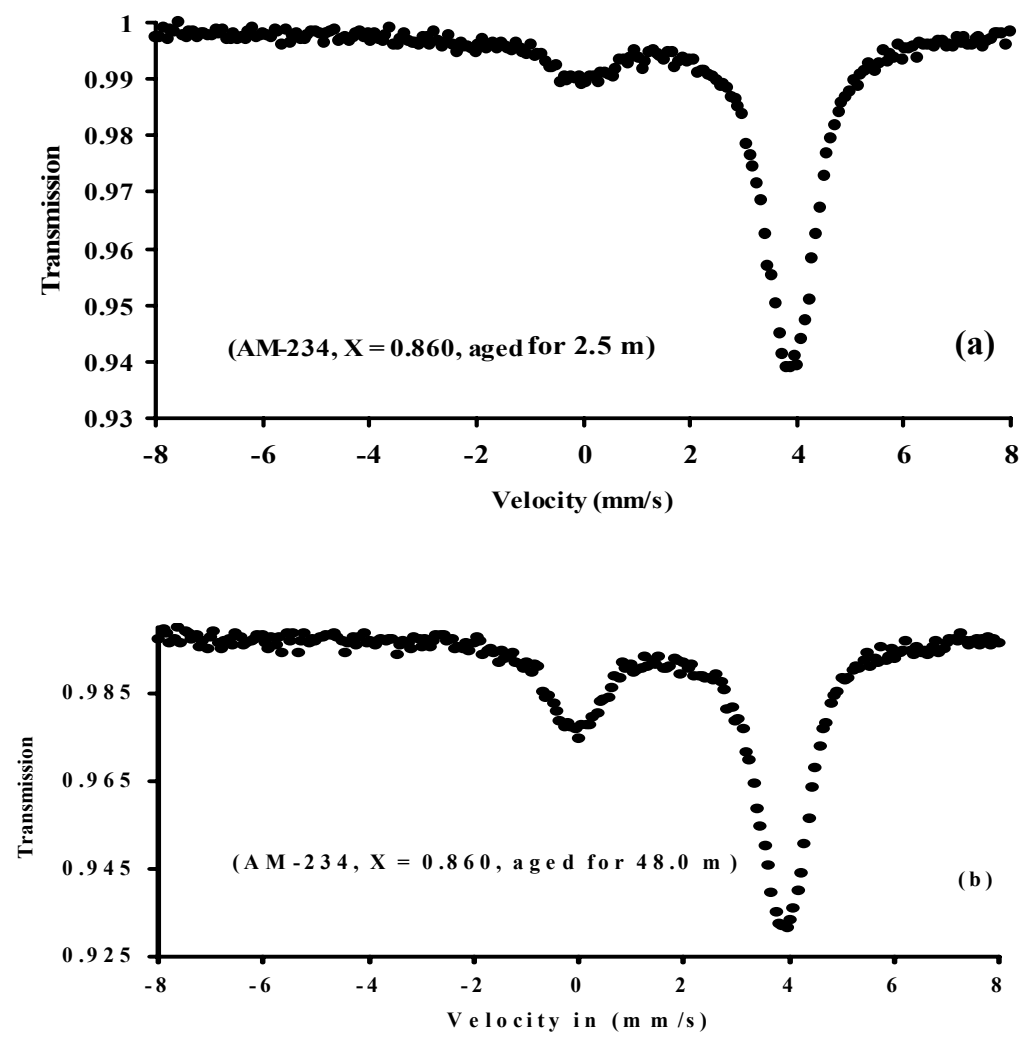

Figure 6: Ambient temperature ${ }^{119} \mathrm{Sn}$ Mössbauer spectrum of the precipitated $\mathrm{Ba}_{1-\mathrm{x}} \mathrm{Sn}_{\mathrm{x}} \mathrm{Cl}_{1+\mathrm{y}} \mathrm{F}_{1-\mathrm{y}}$ versus age: (a) 2.5 month old, (b) 48.0 months old.

The rate of oxidation of the $\mathrm{Ba}_{1-\mathrm{x}} \mathrm{Sn}_{\mathrm{x}} \mathrm{Cl}_{1+\mathrm{y}} \mathrm{F}_{1-\mathrm{y}}$ solid solution prepared by high temperature direct reactions in dry conditions is highly dependent on the $x$ and $y$ composition parameters (fig. 7). At low tin content (low $x$ ), freshly prepared samples have a tin(IV) oxide Mössbauer peak quite stronger than the tin(II) peak (fig. $7 a_{1}$ ). This shows that initial resistance to oxidation is much weaker than in the low tin content fluoride solid solutions. For example, the tin(IV) peak of $\mathrm{Pb}_{1-\mathrm{x}} \mathrm{Sn}_{\mathrm{x}} \mathrm{F}_{2}$ at low tin content $(\mathrm{x}=0.10)$ is barely detectable. After less than three years aging, the tin(IV) peak of figure 7al has much increased and the tin(II) peak is now a minority, therefore passivation is much poorer. When the tin content increases to $\mathrm{x}=0.121$ at $\mathrm{y}=0(\mathrm{Cl} / \mathrm{F}=1)$, the 
tin(IV) peak is weaker than the tin(II) peak, however, it is stronger than that of stoichiometric chloride fluorides.
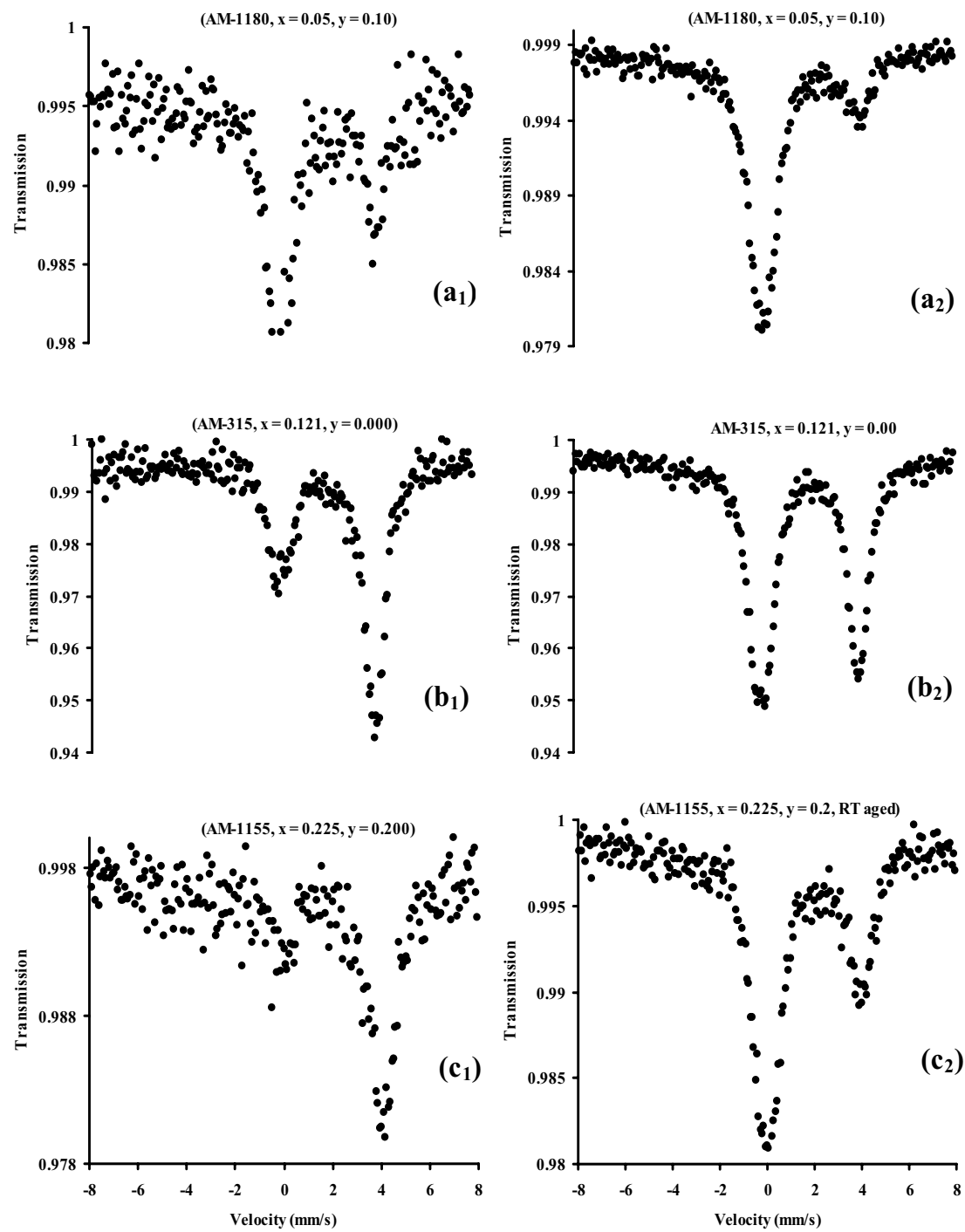

Figure 7: $\quad{ }^{119} \mathrm{Sn}$ Mössbauer spectra of $\mathrm{Ba}_{1-\mathrm{x}} \mathrm{Sn}_{\mathrm{x}} \mathrm{Cl}_{1+\mathrm{y}} \mathrm{F}_{1-\mathrm{y}}$ at $\mathrm{RT}$, prepared by direct reactions under dry conditions (freshly prepared and aged): $\left(\mathrm{a}_{1} \& \mathrm{a}_{2}\right)$ AM-1180, $\mathrm{x}=0.050, \mathrm{y}=0.10$ [freshly prepared $\left(\mathrm{a}_{1}\right)$ and aged for 32 months $\left.\left(a_{2}\right)\right],\left(b_{1} \& b_{2}\right)$ : AM-315, $x=0.121, y=0.000$ [freshly prepared $\left(b_{1}\right)$ and aged for 36.7 months $\left(b_{2}\right)$ ], $\left(c_{1} \& c_{2}\right)$ : AM-1155, $x=0.225, y=0.200$ [freshly prepared $\left(\mathrm{c}_{1}\right)$ and aged 31.0 months $\left.\left(\mathrm{c}_{2}\right)\right]$. 
Upon aging to three years, the tin(IV) peak dominates slightly. This shows that both the oxidation is slower at higher tin content, and passivation is somewhat better, although not great. Near the upper limit of the solid solution in tin $(x=0.225)$ and at high chlorine content $(y=0.200)$, the tin(II) signal predominates by far, however, it is also very weak, which shows that its recoilfree fraction is extremely small. After aging two and a half years, the tin(IV) signal is twice as strong as the tin(II) signal, therefore initial oxidation was not very large, however, passivation was not very good.

These results can be understood, at least in part, from the bonding model of tin in the solid solution. At low $\mathrm{x}, \mathrm{Sn}$ is diluted in the solid and there is little chance of a $\mathrm{Sn}$ being neighbor to another $\mathrm{Sn}$. The coordination of an isolated $\mathrm{Sn}$ is mostly determined by the size of the $\mathrm{Ba}$ site it occupies. Since $\mathrm{Ba}^{2+}$ is quite larger than $\mathrm{Sn}^{2+}$, the latter is loose in its site, i.e. its bonds are weak, resulting in a weak recoil-free fraction and fast oxidation (figs. $7 a_{1} \& 7 a_{2}$ ). At higher tin content, the rest of the solid network has to accept adjustments to satisfy the tin bonding requirements, which allows for stronger bonds, hence a higher recoilfree fraction and some improvement of passivation (figs. $7 b_{1} \& 7 b_{2}$ ). However, at high $x$ and high $y$, the excess chlorine, probably clusters around tin than around barium because there is more room around the smaller tin. However, since $\mathrm{Sn}-\mathrm{Cl}$ bonds are weaker than $\mathrm{Sn}-\mathrm{F}$ bonds, it results in a decrease of recoilfree fraction and passivating power (figs. $7 c_{1} \& 7 c_{2}$ ).

\section{Conclusion}

Mössbauer spectroscopy was an essential method for understanding the complex bonding of tin(II) and its oxidation to tin(IV) in the fluorides and chloride fluorides.

\section{Acknowledgements}

This work was made possible by the support of Concordia University and the Natural Science and Engineering Research Council of Canada. Grateful thanks are also due to the Procter and Gamble Co. (Mason, Ohio) for supporting our Mössbauer laboratory.

\section{References}

[1] Rayner-Canham, G. \& Overton, T., Descriptive Inorganic Chemistry, $3^{\text {rd }}$ ed., Freeman, New York, pp. 78-80, 2002.

[2] Dénès, G., Pannetier, J., Lucas, J. \& Le Marouille, J.Y., About $\mathrm{SnF}_{2}$ stannous fluoride. I. Crystallochemistry of $\alpha-\mathrm{SnF}_{2}$. J. Solid State Chem., 30(3), pp. 335-343, 1979.

[3] Birchall, T., Dénès, G., Ruebenbauer, K. \& Pannetier G., A neutron diffraction and ${ }^{119} \mathrm{Sn}$ Mössbauer study of $\mathrm{PbSnF}_{4}$ and $\mathrm{BaSnF}_{4}$. Hyperf. 29, pp. 1331-1334, 1986. 